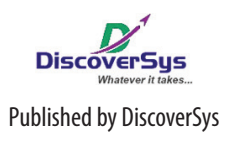

Published by DiscoverSys

\section{Gestational weight gain is a risk factor of stunting among children aged 6-23 months in Bangli District, Bali, Indonesia}

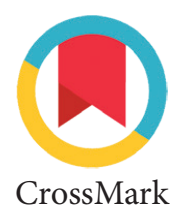

\author{
Ni Putu Ayu Wulan Noviyanti, ${ }^{1 *}$ I Gusti Lanang Sidiartha, ${ }^{2}$ Anak Agung Sagung Sawitri, ${ }^{3}$ \\ Kadek Tresna Adhi ${ }^{3}$
}

\section{ABSTRACT}

Background and purpose: Stunting in children is a chronic nutritional concern that has short-term and long-term health effects. Several studies have shown inconsistent results related to the association between stunting and anemia and increased maternal weight during pregnancy. This study aims to determine anemia during pregnancy, increased body weight and weight gain during pregnancy based on body mass index (BMI) before pregnancy as the risk factors of stunting.

Methods: A case control study was carried out using the baseline data of an intervention study conducted from April to September to prevent stunting in children aged 6-23 months in nine villages in Bangli District, Bali Province. Baseline data collection was conducted from December 2017-February 2018 by interviewing 330 mothers of the children and observation of their ANC records. The number of samples for the case control study was 156 children aged 6-23 months consisting of 78 cases and 78 controls (1:1). Cases were selected by systematic random sampling from 82 children with stunting and controls were selected in the same way from 248 children without stunting. Data analyzed were maternal age at pregnancy, education, employment, number of children, family income, height, hemoglobin level and maternal body weight during pregnancy. Multivariate analysis with logistic regression was conducted to determine the adjusted odds ratio (AOR) of each risk factor.

Results: The increase in maternal weight during pregnancy which is not in accordance with maternal BMI before pregnancy and an increase in maternal weight of $<10$ or $>12.5$ kilograms are significantly associated with stunting with $A O R=3.53$ (95\%Cl: 1,55-8.07) and $A O R=3.31$ (95\%Cl: 1.24-8.85). Hemoglobin <11 $\mathrm{gr} / \mathrm{dL}$ during pregnancy was not found to be significantly associated with stunting ( $A O R=5.02 ; 95 \% \mathrm{Cl}: 0.80-31.71$ ).

Conclusion: The increase of maternal weight during pregnancy which is not suitable with BMI before pregnancy and an increase in maternal weight of $<10$ or $>12.5$ kilograms are risk factors for stunting in children aged 6-23 months. In addition to monitoring the increase of maternal weight during pregnancy, it is important to consider the mother's BMI before pregnancy in order to reduce the risk of stunting.
1Public Health Postgraduate Program, Faculty of Medicine, Udayana University,

${ }^{2}$ Department of Pediatrics, Faculty of Medicine, Udayana University, ${ }^{3}$ Department of Public Health and Preventive Medicine, Faculty of Medicine, Udayana University

*Correspondence to:

Ni Putu Ayu Wulan Noviyanti, Public Health Postgraduate Program, Faculty of Medicine, Udayana University, wulann98@gmail.com
Keywords: stunting, children aged 6-23 months, anemia, increased body weight of pregnant women, Bali

Cite This Article: Noviyanti, N.P.A.W., Sidiartha, I.G.L., Sawitri, A.A.S., Adhi, K.T. 2019. Gestational weight gain is a risk factor of stunting among children aged 6-23 months in Bangli District, Bali, Indonesia. Public Health and Preventive Medicine Archive 7(1): 14-19. D01:10.15562/phpma.v7i1.188

\section{INTRODUCTION}

Stunting in children under the age of five is a chronic nutritional concern that occurs globally, including in Indonesia. ${ }^{1}$ In 2016, 22.9\% of children under five years of age around the world were recorded as stunted. ${ }^{2}$ The proportion of stunting among under five children in Indonesia is increasing, started from $18.0 \%$ in $2007,19.2 \%$ in 2013 and $19.3 \%$ in 2018. ${ }^{3}$ The nutritional status monitoring survey conducted in Bali Province in 2016 showed that $19.7 \%$ of children under five experienced stunting. ${ }^{4}$

Stunting that occurs in the first 1000 days of life, which is from conception to two years old, will cause short-term and long-term health effects. ${ }^{5}$ According to the WHO conceptual framework on childhood stunting, the stunting-related factors in children are community and societal, household and family factors, inadequate complementary feeding, breastfeeding and infection. ${ }^{6}$ Maternal factors include household and family factors consisting of poor nutrition during pre-conception, pregnancy and lactation, short maternal stature, infection, adolescent pregnancy, mental health, intra uterine growth retardation and preterm birth, short birth spacing and hypertension. ${ }^{6}$

Some studies indicate that the incidence of stunting is influenced by maternal factors including a lack of maternal nutrition before pregnancy, during pregnancy and lactation, inadequate antenatal care (ANC), maternal age, maternal height, infectious disease, maternal mental health, hypertension, anemia, low body mass index (BMI) and weight gain during pregnancy. ${ }^{5,7-9}$ Several studies have shown inconsistent results regarding the association between stunting in infants with anemia and increased maternal weight gain during pregnancy. ${ }^{8-15,26}$ This study aims to determine anemia 
during pregnancy, increased body weight and weight gain during pregnancy based on body mass index (BMI) before pregnancy as the risk factors of stunting in children aged 6-23 months.

\section{METHODS}

This is a case control study that used the baseline data of an intervention study conducted in April to October 2018 to prevent malnutrition in children aged 6-23 months in nine villages of Susut Sub-District, Bangli District, Bali Province. Bangli District is ranked second of the highest prevalence $(25.7 \%)$ of stunting among children aged under five in Bali Province after Karangasem District (26\%). ${ }^{4}$ The nutritional status monitoring survey conducted in Bangli District in 2016 indicated that the proportion of children under five with stunting (9\%) in Susut Sub-District was higher than the proportion of underweight (8\%) and wasted underfives $(2.7 \%)$.

Baseline data collection of the intervention study was conducted from December 2017-February 2018 by interviewing 330 mothers of the children and observing their ANC records. The number of samples for the case control study was 156 children aged 6-23 months consisting of 78 cases and 78 controls (1:1). The number of samples was determined based on the confidence level of $95 \%$, power of $80 \%$, the proportion of anemia during pregnancy in non-stunting children at $25 \%^{11}$ and anticipated odd ratio of 2.5. Case definition of stunting is if the $\mathrm{z}$-score was $<-2 \mathrm{SD}$ based on indicators of length-for-age. Of 330 children aged 6-23 months at the time of baseline data collection there were 82 stunted children and 78 children selected as cases by systematic random sampling. The number of controls was 78 children whom also selected in the same way from 248 children who were not stunted.

Data analyzed were maternal age at pregnancy, education, employment, number of children, family income, height, hemoglobin level and maternal body weight gain during pregnancy. Hemoglobin levels recorded in the $\mathrm{MCH}$ books were grouped into $<11 \mathrm{gr} / \mathrm{dL}$ (anemia) and $\geq 11 \mathrm{gr} / \mathrm{dL}$ (not anemia). ${ }^{17}$ Weight gain during pregnancy was obtained from the difference between pre-pregnancy weight and pre-birthing weight recorded in the ANC book and confirmed by interview. The increase of body weight was grouped into two, namely $10-12.5 \mathrm{~kg}$ and $<10$ or $>12.5 \mathrm{~kg}$. The suitability of increasing maternal weight during pregnancy with BMI before pregnancy was grouped into "not suitable" if during pregnancy the increase in body weight is less or exceeds the standard range of the Institute of Medicine (IOM) and "suitable" if during pregnancy the weight gain is in the standard range IOM. ${ }^{18}$ Increased weight categorized as "suitable with" the IOM standard is $12.5-18 \mathrm{~kg}$ in mothers who are underweight $(\mathrm{BMI}<18.5), 11.5-16 \mathrm{~kg}$ in women with a normal BMI (BMI=18, 5-22.9), 7-11.5 kg in mothers who were overweight (BMI=23.0-27.4) and $5-9 \mathrm{~kg}$ in obese mothers (BMI $\geq 27.5) .{ }^{18}$ Family income was grouped according to Bangli District's minimum wage which is $<$ IDR $2,128,253$ and $\geq$ IDR $2,128,253 .^{19}$

Bivariate analysis was conducted to obtain crude odd ratios (OR) and multivariate analysis was conducted using binomial logistic regression using STATA 12.1 to obtain the adjusted odd ratio (AOR) of each variable. This study has been approved by the Ethics Committee of the Faculty of Medicine, Udayana University/Sanglah General Hospital in Denpasar on May 14, 2018.

\section{RESULTS}

Table 1 shows that the characteristics of cases and controls did not differ by sex $(p=0.08)$ and age $(p=0.74)$. Table 2 shows the crude OR of maternal age at pregnancy, ANC visit frequency, maternal height, maternal nutritional status before pregnancy, maternal education, maternal occupation, family income, body weight increase and its suitability with BMI, hemoglobin level and number

Table 1 Characteristics of children aged 6-23 months

\begin{tabular}{lccc}
\hline & Cases & Controls & $\mathbf{p}^{*}$ \\
\cline { 2 - 4 } Characteristics & $\mathbf{n}(\%)$ & $\mathbf{n}(\%)$ & \\
\hline Sex & & & 0.08 \\
$\quad$ Male & $45(57.7)$ & $34(43.6)$ & 0.74 \\
$\quad$ Female & $33(42.3)$ & $44(56.4)$ & \\
Age (months) & & $30(38.5)$ & $48(61.5)$ \\
12-23 & $32(41.0)$ & $46(59.0)$ & \\
6-11 & & & \\
\hline
\end{tabular}

*) Chi-Square test 
Tabel 2 Crude odd ratio of maternal factors for stunting among children aged 6-23 months

\begin{tabular}{|c|c|c|c|c|c|}
\hline & Cases & Controls & & & \\
\hline Variables & n (\%) & n (\%) & Crude OR & $95 \% \mathrm{Cl}$ & $\mathbf{p}$ \\
\hline \multicolumn{6}{|l|}{ Maternal age at pregnancy (years) } \\
\hline$<20$ or $>35$ & $17(21.8)$ & $16(20.5)$ & 1.08 & $0.50-2.33$ & 0.85 \\
\hline $20-35$ & $61(78.2)$ & $62(79.5)$ & & & \\
\hline \multicolumn{6}{|l|}{ ANC visit frequency (times) } \\
\hline$<9$ & $45(57.7)$ & $49(62.8)$ & 0.81 & $0.43-1.53$ & 0.51 \\
\hline$\geq 9$ & $33(42.3)$ & $29(37.2)$ & & & \\
\hline \multicolumn{6}{|l|}{ Maternal height } \\
\hline$<150 \mathrm{~cm}$ & $19(24.4)$ & $11(14.1)$ & 1.96 & $0.86-4.46$ & 0.10 \\
\hline$\geq 150 \mathrm{~cm}$ & $59(75.6)$ & $67(85.9)$ & & & \\
\hline \multicolumn{6}{|l|}{ BMI before pregnancy } \\
\hline Underweight & $9(11.5)$ & $6(7.7)$ & 1.49 & $0.76-2.93$ & 0.25 \\
\hline Overweight & $25(32.1)$ & $33(42.3)$ & 0.75 & $0.25-2.30$ & 0.62 \\
\hline Normal weight & $44(56.4)$ & $39(50.0)$ & & & \\
\hline \multicolumn{6}{|l|}{ Maternal education } \\
\hline Junior high school & $48(61.5)$ & 35 (44.9) & 1.97 & $1.04-3.72$ & 0.04 \\
\hline Senior high school and above & $30(38.5)$ & $43(55.1)$ & & & \\
\hline \multicolumn{6}{|l|}{ Maternal employment } \\
\hline Employed & $42(53.8)$ & $38(48.7)$ & 1.23 & $0.66-2.30$ & 0.52 \\
\hline Unemployed & $36(46.2)$ & $40(51.3)$ & & & \\
\hline \multicolumn{6}{|l|}{ Family income } \\
\hline Below minimum wage & $52(66.7)$ & $40(51.3)$ & 1.90 & $1.00-3.63$ & 0.05 \\
\hline Minimum wage and above & $26(33.3)$ & $38(48.7)$ & & & \\
\hline \multicolumn{6}{|l|}{ Increase in body weight } \\
\hline$<10 \mathrm{~kg}$ or $>12,5 \mathrm{~kg}$ & $64(82.1)$ & $50(64.1)$ & 2.56 & $1.22-5.37$ & 0.01 \\
\hline $10-12,5 \mathrm{~kg}$ & $14(17.9)$ & $28(35.9)$ & & & \\
\hline \multicolumn{6}{|l|}{ Body weight increase with BMI } \\
\hline Unsuitable & $49(62.8)$ & $24(30.8)$ & 3.80 & $1.96-7.39$ & $<0.01$ \\
\hline Suitable & $29(37.2)$ & $54(69.2)$ & & & \\
\hline \multicolumn{6}{|l|}{ Hemoglobin level $^{*}$} \\
\hline$<11$ gr/dL (anemia) & $5(8.9)$ & $2(3.1)$ & 3.04 & $0.57-16.33$ & 0.25 \\
\hline$\geq 11$ gr/dL (notanemia) & $51(91.1)$ & $62(96.9)$ & & & \\
\hline \multicolumn{6}{|l|}{ Number of children } \\
\hline$>2$ & $27(34.6)$ & $15(19.2)$ & 2.22 & $1.07-4.62$ & 0.03 \\
\hline $1-2$ & $51(65.4)$ & $63(80.8)$ & & & \\
\hline
\end{tabular}

*There were 36 missing hemoglobin data and statistical tests were performed with Fisher's Exact

Table 3 Adjusted odd ratio of maternal factors for stunting in children aged 6-23 months

\begin{tabular}{lccc}
\hline Variables & AOR & $\mathbf{9 5 \%} \mathbf{C l}$ & $\mathbf{p}$ \\
\hline Increase in body weight & & & 0.02 \\
$\quad<10 \mathrm{~kg}$ or $>12,5 \mathrm{~kg}$ & 3.31 & $1.24-8.85$ & \\
$\quad 10-12,5 \mathrm{~kg}$ & 1.00 & & $<0.01$ \\
Suitability of body weight increase with BMI & & $1.55-8.07$ & \\
$\quad$ Unsuitable & 3.53 & & \\
$\quad$ Suitable & 1.00 & & \\
\hline
\end{tabular}


Table 3 Continue

\begin{tabular}{|c|c|c|c|}
\hline Variables & AOR & $95 \% \mathrm{Cl}$ & $\mathbf{p}$ \\
\hline \multicolumn{4}{|l|}{ Hemoglobin level } \\
\hline$<11$ gr/dL (anemia) & 5.02 & $0.79-31.71$ & 0.09 \\
\hline$\geq 11$ gr/dL (not anemia) & 1.00 & & \\
\hline \multicolumn{4}{|l|}{ Children's sex } \\
\hline Male & 1.69 & $0.75-3.82$ & 0.21 \\
\hline Female & 1.00 & & \\
\hline \multicolumn{4}{|l|}{ Maternal height } \\
\hline$<150 \mathrm{~cm}$ & 1.50 & $0.54-4.21$ & 0.44 \\
\hline$\geq 150 \mathrm{~cm}$ & 1.00 & & \\
\hline \multicolumn{4}{|l|}{ Maternal education } \\
\hline Junior high school & 1.07 & $0.45-2.53$ & 0.88 \\
\hline Senior high school and above & 1.00 & & \\
\hline \multicolumn{4}{|l|}{ Family income } \\
\hline Below minimum wage & 1.60 & $0.67-3.85$ & 0.29 \\
\hline Minimum wage and above & 1.00 & & \\
\hline \multicolumn{4}{|l|}{ Number of children } \\
\hline$>2$ & 0.72 & $0.45-1.15$ & 0.17 \\
\hline $1-2$ & 1.00 & & \\
\hline
\end{tabular}

of children. All variables with $\mathrm{p}$ values $<0.25$ were included in the model for multivariate analysis using logistic regression. Table 3 shows that the increase of body weight during pregnancy that not suitable with BMI (AOR=3.53; 95\%CI: 1.55-8.07) and an increase in maternal weight $<10$ or $>12.5$ kilograms $(\mathrm{AOR}=3.31 ; 95 \% \mathrm{CI}: 1.24-8.85)$ increased the risk of stunting in children aged 6-23 months.

\section{DISCUSSION}

This study showed that stunting in children aged 6-23 months was associated with the increase in body weight during pregnancy, which was not in accordance with the mother's BMI before pregnancy, and an increase in maternal weight $<10$ kilograms or $>12.5$ kilograms. Based on the Indonesian Ministry of Health Guidelines, an increase in body weight during pregnancy of $10-12.5 \mathrm{~kg}$ is recommended for mothers with "normal" or "ideal" weight before pregnancy, ${ }^{20}$ while the results of this study indicate that maternal BMI before pregnancy needs to be taken into account in monitoring weight gain during pregnancy. If the mother before pregnancy was underweight and only pays attention to weight gain without taking into account the BMI before pregnancy, then when the mother experiences a weight gain of $16 \mathrm{~kg}$ during pregnancy, it increases the odds of stunting. But if taking into account the mother's BMI before pregnancy, the increase in body weight of $16 \mathrm{~kg}$ did not increase the odds of stunting.
Studies conducted in Yogyakarta and Bogor with a case control design among children under five also showed similar results to this study. ${ }^{14,21}$ Several studies in other countries also showed that an increase in maternal weight during pregnancy which is not in accordance with BMI will increase the risk of children to experience growth disorders. ${ }^{22-25}$ Studies conducted in India and Guatemala show that increasing weight $<10$ kilograms during pregnancy increases the risk of stunting of two-year-olds. ${ }^{12,23}$ Several other studies also show that maternal weight gain in the first to third trimester is associated with femur bone length and fetal tibia $(\mathrm{p}<0.05)$ and the length of the baby at birth $(\mathrm{p}<0.001) .23,24,26$

Our study shows that anemia was not significantly associated with stunting in children aged 6-23 months. In this study maternal hemoglobin levels were obtained from the records in the ANC book and as many as 36 mothers had unrecorded hemoglobin levels. In addition, there were only 7 out of 120 mothers (5.83\%) who had hemoglobin levels $<11 \mathrm{gr} / \mathrm{L}$. In the multivariate analysis it was found that the AOR of anemia was quite high at 5.02 but not statistically significant with $95 \% \mathrm{CI}$ : 0.79-31.71. This is probably due to the small number of samples of anemic mothers. The results of this study are similar to a study conducted in Yogyakarta with a case control design which shows that there was no significant association between anemia during pregnancy and stunting. ${ }^{11}$ Another 
study conducted in Semarang with a cohort design, however, showed that anemia measured in the third trimester of pregnancy was associated with the length of the infant. ${ }^{26}$ The hemoglobin levels of pregnant women in the study were measured using the cyanmethemoglobin method. ${ }^{26}$

The limitations of this study are data on hemoglobin levels, maternal body weight during pregnancy and before delivery were obtained from secondary data that were recorded in the ANC book. There is a possibility of different tools and ways to measure hemoglobin levels and maternal weight before pregnancy and before giving birth. In addition, in this study, the number of pregnant women who had anemia were limited so that they could not show significant differences. Finally, this study was conducted in one sub-district, so generalization of the results into a wider population needs to be taken in caution.

\section{CONCLUSION}

Unsuitable weight gain during pregnancy with mother's BMI before pregnancy and weight increase of $<10$ kilograms or $>12.5$ kilograms during pregnancy are risk factors for stunting in children aged 6-23 months. In addition to monitoring the increase in maternal weight during pregnancy, the mother's BMI before pregnancy should be considered in order to reduce the risk of stunting.

\section{ACKNOWLEDGEMENT}

We would like to thank the Indonesia Ministry of Research, Technology and Higher Education for funding the baseline data collection of the intervention study. We would also like to thank all respondents who have participated in this study, and the Head of the Susut I Public Health Center and staff who have assisted the implementation of this study.

\section{REFERENCES}

1. UNICEF. Levels and trends in child malnutrition. New York; 2015.

2. UNICEF. Levels and trends in child malnutrition. Washington DC; 2017.

3. The Ministry of Health of Indonesia. Riset Kesehatan Dasar tahun 2018 [The 2018 Indonesia Basic Health Research]. 2018.

4. Bali Province Health Office. Laporan hasil pemantauan status gizi dan pemantauan konsumsi gizi (PSG-PKG) Provinsi Bali 2016 [Report on the results of 2016 Bali Province nutritional status and nutrition consumption monitoring survey]. Denpasar; 2016.

5. WHO. Childhood stunting: Challenges and opportunities. 2013.

6. Nkurunziza S, Meessen B, Van geertruyden J-P, Korachais C. Determinants of stunting and severe stunting among Burundian children aged 6-23 months: evidence from a national cross-sectional household survey, 2014. BMC Pediatrics. 2017;17(176):1-14.
7. Najahah I, Adhi KT, Pinatih GNI. Faktor risiko balita stunting usia 12-36 bulan di Puskesmas Dasan Agung, Mataram, Provinsi Nusa Tenggara Barat [Risk factors of stunting among children aged 12-36 months at Dasan Agung Public Health Centre, Mataram, West Nusa Tenggara]. Public Health and Preventive Medicine Archive. 2013;1(2):134-41.

8. Danaei G, Andrews KG, Sudfeld CR, Nther Fink G, Mccoy DC, Peet E, et al. Risk factors for childhood stunting in 137 Developing Countries: A comparative risk assessment analysis at global, regional, and country levels. PLoS Medicine. 2016;13(11):1-18.

9. Zaif RM, Wijaya M, Hilmanto D. Hubungan antara riwayat status gizi ibu masa kehamilan dengan pertumbuhan anak balita di Kecamatan Soreang Kabupaten Bandung [The association between the history of gestational nutritional status with the growth of children under five years old in Soreang Sub-District, Bandung District]. Jurnal Sistem Kesehatan. 2016;2(3):156-63.

10. Ruaida N. Hubungan anemia ibu hamil dengan kejadian stunting pada anak usia 6-24 bulan di Kota Yogyakarta (tesis) [The association between gestational anemia and stunting among children aged 6-24 months in Yogyakarta (thesis)]. Universitas Gadjah Mada; 2013.

11. Warsini KT, Hadi H, Nurdiati DS. Riwayat KEK dan anemia pada ibu hamil tidak berhubungan dengan kejadian stunting pada anak usia 6-23 bulan di Kecamatan Sedayu, Bantul, Yogyakarta [History of malnutrition and anemia in pregnant women are not associated with stunting among children aged 6-23 months in Sedayu Sub-District, Bantul. Yogyakarta]. Jurnal Gizi dan Dietetik Indonesia. 2016;4(1):29-40.

12. Pandey P, Bajpai P, Jain S, Sharma A. Maternal empowerment holds the key to reducing stunting during first 1000 days of life: Evidence from a case-controlled study. Annals of Tropical Medicine and Public Health. 2017;10(3):667-77.

13. Prabandari Y, Hanim D, Cilmiaty RA, Dono Indarto D. Hubungan kurang energi kronik dan anemia pada ibu hamil dengan status gizi bayi usia 6-12 bulan di Kabupaten Boyolali [The association of chronic malnutrition and anemia among pregnant women with the nutrition status of infants aged 6-12 months in Boyolali District]. Penelitian Gizi dan Makanan. 2016;39(1):1-8.

14. Erowati D. Pengaruh faktor ibu dan anak pada periode 1000 hari pertama kehidupan terhadap kejadian stunting pada anak usia 12-24 bulan [The influence of maternal and child factors during the first 1000 days period of life towards stunting among children aged 12-24 months. Universitas Gadjah Mada; 2016.

15. Torlesse H, Cronin AA, Sebayang SK, Nandy R. Determinants of stunting in Indonesian children: evidence from a cross-sectional survey indicate a prominent role for the water, sanitation and hygiene sector in stunting reduction. BMC Public Health. 2016;16(669):1-11.

16. Bangli District Health Office. Hasil Pemantauan Status Gizi (PSG) tahun 2017 di Kabupaten Bangli [The results of 2017 nutritional status monitoring survey in Bangli District]. Bangli District; 2017.

17. World Health Organization. Haemoglobin concentrations for the diagnosis of anaemia and assessment of severity. World Health Organization; 2011.

18. Institute of Medicine. Weight gain during pregnancy: re-examining the guidelines. Washingron, D.C.: The National Academies Press; 2009.

19. Government of Bali Province. Peraturan Gubernur Bali Nomor 65 Tahun 2017 tentang Upah Minimum Kabupaten/Kota [The Bali Province Governor Act No. 65 Year 2017 on the Local District/City Minimum Wages]. 2017.

20. Ministry of Health of Indonesia. Kehamilan: 1000 hari pertama periode emas janin [Pregnancy: The first 1000 days of infants' gold period]. Ministry of Health of Indonesia. 2012. Available from: http://gizi.depkes.go.id/wp-content/uploads/2012/11/FA-LEAFLET -KEHAMILAN.pdf 
21. Pusparini, Ernawati F, Briawan H. Indeks massa tubuh rendah pada awal kehamilan dan defisiensi Vitamin A pada trimester kedua sebagai faktor risiko gangguan pertumbuhan linier pada bayi lahir [Low BMI during early pregnancy and Vitamin A deficiency in the second trimester as risk factors of linier growth disorders among infants]. Jurnal Gizi Pangan. 2016;11(3):191-200.

22. Black RE, Allen LH, Qar Z, Bhutta A, Caulfi LE, De Onis $\mathrm{M}$, et al. Maternal and child undernutrition: global and regional exposures and health consequences. Lancet. 2008;371(9608):243-60.

23. Neufeld LM, Haas JD, Grajéda R, Martorell R. Changes in maternal weight from the first to second trimester of pregnancy are associated with fetal growth and infant length at birth. The American Journal of Clinical Nutrition. 2004;79(4):646-52.

24. Ota E, Haruna M, Suzuki M, Anh DD, Tho LH, Tam NTT, et al. Maternal body mass index and gestational weight gain and their association with perinatal outcomes in Viet Nam. Bulletin of the World Health Organization. 2011;89:127-36.
25. Soltani H, Lipoeto NI, Fair FJ, Kilner K, Yusrawati Y. Pre-pregnancy body mass index and gestational weight gain and their effects on pregnancy and birth outcomes: a cohort study in West Sumatra, Indonesia. BMC Women's Health. 2017;17(102):7-12.

26. Ruchayati F. Hubungan kadar hemoglobin dan lingkar lengan atas ibu hamil trimester III dengan panjang bayi lahir di Puskesmas Halmahera Kota Semarang [The association of hemoglobin levels and upper arm circle among third trimester pregnant women with the length of infants at Halmahera Public Health Center, Semarang City]. Jurnal Kesehatan Masyarakat. 2012;1(2):578-85.

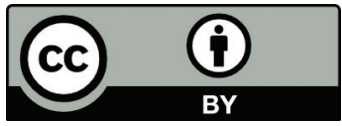

This work is licensed under a Creative Commons Attribution 